\title{
Arkiverne og den nye historieformidling
}

\section{Af Charlotte S.H. Jensen, Morten Mortensen og Johnny Wфllekar}

\section{Indledning}

Formidling af historie begyndte, da menneskeheden for tusinder af år siden udviklede et sprog, hvormed fortællinger om, hvem man var, kunne gives videre til næste generation. Ja, spørgsmålet er, om ikke sproget opstod bl.a. af behovet for at fortælle sin historie: Hvem er jeg, hvem er vi? Hvorfra kommer jeg, hvorfra kommer vi? Sprog og formidling af historie er altså et ældgammelt makkerpar, der op gennem tiden har taget mange former: Den mundtlige beretning, fortællinger fastholdt af symboler og tegninger på klippevægge i huler, skrevne tegn på lertavler, papyrus og pergament. Med bogtrykkerkunstens opfindelse blev det muligt at nå endnu flere mennesker, og i det 20. århundrede eksploderede historieformidlingen i utallige elektroniske variationer og former - den seneste er Internettet. I dag, blot 10-15 år efter at Internettet blev allemandseje, findes et næsten uoverskueligt antal hjemmesider, der på den ene eller anden måde omhandler historiske emner. Variationen af historiske hjemmesider er stor og går fra enkeltpersoners formidling af egen historie og slægtshistorie over leksikale opslagsværker til store hjemmesider, der omhandler generelle historiske emner.

Men hvordan finder man hoved og hale på Internettets enorme udbud af historiske hjemmesider? Hvilke hjemmesider kan man stole på? Hvordan vurderer man lødigheden af de oplysninger og fortolkninger, man støder på i sin søgning på Internettet? Det er nogle af de spørgsmål, man må stille sig, når man bevæger sig ud på Internettet for at shoppe historiske oplysninger. Man kan sikre sig oplysninger af forholdsvis høj og pålidelig karakter ved at anvende hjemmesider, der på en eller anden måde har fundament i nogle anerkendte historiske institutioner. Dermed ikke være sagt, at anderledes funderede hjemmesider ikke også kan være lødige, men chancen for, at indholdet er underlagt kompetente, faglige kriterier, er størst ved anerkendte, historiske institutioner.

I det følgende vil erfaringerne fra tre sådanne danske, historiske hjemmesider blive beskrevet. De repræsenterer tre typer af historiske hjemmesider: 1) Historie-online, som repræsentant for den generelle historiske hjemmeside, der i princippet dækker hele det historiske spektrum geografisk og emnemæssigt. 2) Historiefyn som repræsentant for den lokalt og regionalt afgrænsede historiske hjemmeside, og endelig 3) NFI - Netværk For Folkelig Idrætshistorie som den emnemæssigt specialiserede historiske hjemmeside.

\section{Det generelle: Historie-online}

Historie er et emne, som interesserer mange - ja faktisk stadig flere. Den »historie- 
løshed «, som fra tid til anden omtales med bekymring i medierne, synes at være noget overdrevet. Danskerne er vilde med kulturarv ifølge en ny rapport, som netop er udgivet af Kulturarvsstyrelsen (www. kulturarv.dk). Over 70 pct. af både borgere og virksomheder i Danmark mener, at kulturarv kan være med til at støtte den regionale udvikling. Endnu flere - over 90 pct. - af danskerne mener, at det er vigtigt at bevare og udvikle kulturarven. Og lige så mange mener, at kulturarven skaber lokal identitet.

To nye spændende og brede historiemagasiner har netop set dagens lys, antallet af slægtsforskere på arkivernes læsesale vokser, og om aftenen sidder far måske klar med fjernbetjeningen for at zappe over på alt om 2. verdenskrig på Discovery eller History Channel, mens mor er i sving med Maria Hellebergs seneste roman. Der er rige muligheder for at få sin historieinteresse næret.

\section{En anderledes historie-site}

Historieinteressen kan naturligvis også tilfredsstilles på Nettet, hvor jo enhver kulturarvsinstitution med respekt for sig selv har større eller mindre præsentationer. Men fælles for disse institutioner er i reglen, at de tager udgangspunkt i institutionen og netop dennes materiale/samlinger. Og det er sjældent, at fortiden har organiseret sig så hensigtsmæssigt, at kun én institution, institutionstype eller ét medie kan dække den historieinteresseredes behov. Den aktivt historieinteresserede museumsgænger og/eller arkivbruger har behov for oplysninger om åbningstider mm. og vejledninger, som giver inspiration eller konkrete brugsoplysninger om institutionerne. Disse institutionsnære oplysninger er selvsagt væsentlige - men måske ikke af en karakter, der udbygger og kvalificerer interessen for historie.

Som paraplyorganisation for den danske historiske verden har Dansk Historisk Fællesråd på webadressen www.historie-online.dk opbygget en anderledes historiesite. Historie-online (H-o) er ikke som de andre, fordi den ikke tager udgangspunkt i én institution eller institutionstype og heller ikke i en særlig form for historisk interesse (genealogi, jernbanehistorie, amatørarkæologi etc.). H-o tager udgangspunkt i historie som sådan $i$ alle former og afarter, og den er - i modsætning til andre sites - baseret på såvel nyheder som resurser uden institutionelt udgangspunkt.

$\mathrm{H}-\mathrm{o}$ blev lanceret i februar 2003. Siden da er det gået støt op ad bakke, således at siten pr. 1. oktober 2005 har ca. 2300 abonnenter på nyhedsbrev. Det månedlige antal unikke besøgende ligger mellem 25.$30.000 \mathrm{og}$ antallet af sidevisninger omkring 100.000. Det er altså gået fremad siden starten og ligeså mht. tilgang i antallet af modtagere på nyhedsbrev.

\section{Nyhedsbrev som udviklingsværkt $\varnothing j$}

Nyhedsbrevet er et redskab til nyhedsformidling, men via de statistiske hjælpemidler også et udviklingsværktøj, der har en nøje sammenhæng med sitens udformning. Men ét er, hvor mange der abonnerer - noget andet er, hvor mange der læser nyhedsbrevene. Ud fra de tilknyttede statistikker er det tydeligt, at visse nyhedsbreve har flere læsere end abonnenter. Et eksempel kunne fx være nyhedsbrevet for uge $7 \mathrm{i}$ 2005, som blev udsendt til 1867 abonnenter - og læst af 2800. Dette forhold kan kun forklares ved, at nyhedsbrevene sendes videre til venner og kolleger. Nyhedsbrevet og siten formidles på denne måde »privat - ligesom det sker ved scriptet 


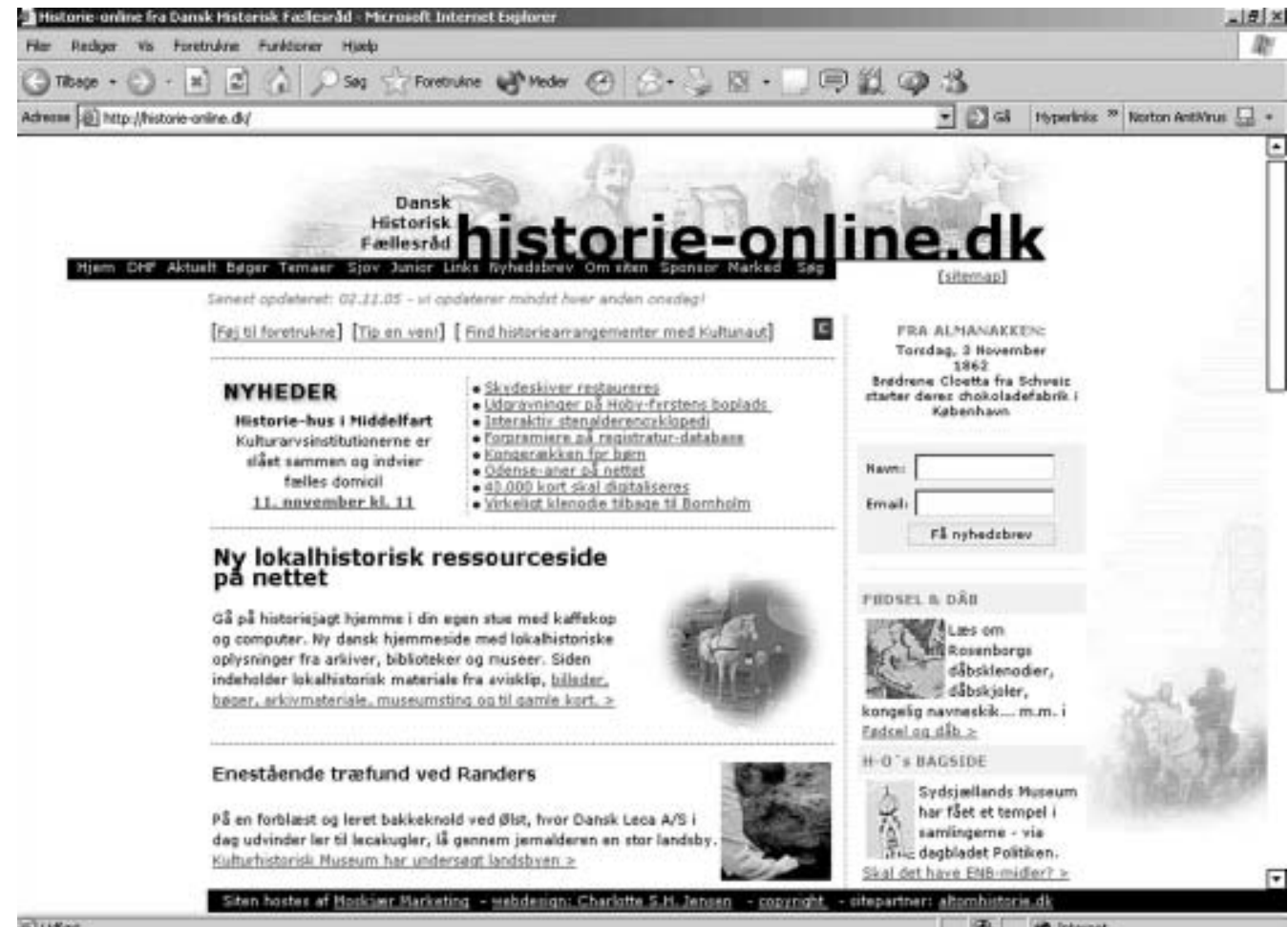

ฮư⿰亻

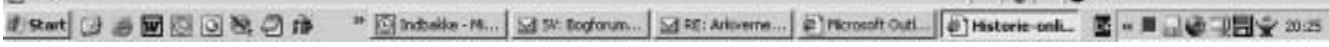

Historie-onlines forside skifter ved hver opdatering - dvs. pt. én gang om ugen. Nyhederne disponeres med en hovednyhed, et par sekundare og mellem fire og seks yderligere. Desuden kan brugerne altid få adgang til relevante temaer m.m. via forsiden.

»send-til-en-ven«, som er installeret på alle nyhedssider. At dette også anvendes, ses i de tilfælde, hvor en side opnår et besøgstal, der ligger væsentlig højere end antallet af klik fra nyhedsbrevet. I statistikken over klik fra nyhedsbrev er det desuden tydeligt, hvilke emner der interesserer sitens brugere. Nyheder om nye arkæologiske fund/donationer til museer, nye resurser på Nettet (fx adresseavisen), nye webudstillinger samt aktiviteter og »årstidsfeatures « .

Nyhedsbrevet genererer trafik og erindrer brugerne om muligheder og resurser på websiten. Desuden er nyhedsbrevet gennem det tilhørende statistikmodul - en væsentlig kilde til information om, hvilke emner der interesserer sitens brugere. En website bør laves for brugerne og ikke for producenterne. Den må derfor tage en væsentlig del af sit udgangspunkt i de emner og muligheder, som sitens målgruppe interesserer sig for.

DHF's oprindelige idé var, at siten skulle rumme nyheder med høj opdateringsfrekvens, hvilket er lykkedes og utvivlsomt en del af årsagen til den betydelige interesse, som siten har kunnet generere. Siten opdateres fast én gang om ugen - nemlig hver onsdag, når e-nyhedsbrevet »udkommer «. Disse rummer nyt om fund, udstillinger, seminarer og temamøder, nye bøger listes i »Bogstakken« og i »Bogfeature« 
findes anmeldelser af aktuelle publikationer etc. Brevet er tilrettelagt sådan, at et par linjer om hver af de aktuelle nyheder er suppleret med link til nyhedens placering på siten.

Et tungtvejende $\varnothing$ nske har også været bredde, dvs. at holde de interesserede ajour med nyt fra hele den historiske verden. Men målet har ikke kun været at skabe en site med mange brugere for sitens egen skyld. Den grundlæggende filosofi er »at samle for at sprede « - dvs. at skabe et informationsfokus, der også viser brugerne videre ud til museer, arkiver, foreninger og andre historiske hjemmesider. Desuden bestræber siten sig på at give et vist overblik - for både læg og lærd. Og i dag spænder den faktisk fra et anmelderkorps af børn til annoncering af videnskabelige seminarer på engelsk.

\section{Varige resurser og lette elementer}

Nyheder er imidlertid kun én af de muligheder, som tilbydes. H-o rummer desuden en lang række varige resurser om historiske emner. Der findes en - efterhånden længere række af specialsider, dels et større modul om dansk oldtid og dels en række mindre sider, som giver smagsprøver på forskellige historiske »specialiteter«, som fx gamle lægeplanter og husdyrracer.

Yderst populære er en række moduler om livets og årets fester - hvoraf de sidste jo er stærkt aktuelle med mellemrum. Dette skaber mulighed for løbende at trække disse elementer frem og dermed præsentere et aktuelt tema. Derved stiller H-o viden og kulturhistorisk perspektivering af aktuelle emner til rådighed. For en historiesite med bred målgruppe er det vigtigt at orientere sig mod forhold, emner og begi- venheder, som målgrupperne interesserer sig for. I modsat fald mindskes oplevelsen af personlig relevans.

I den lettere ende »Historie for sjov « er der mulighed for at sende historiske postkort, hente pc-tapeter og screensavere, prøve forskellige små quizzer m.m. Netop denne aktivitetsdel skal ses som en opblødning af de mere teksttunge elementer. For hvorfor skal et møde med historie og kulturarv nødvendigvis være en teksttung og intellektuelt krævende affære? På mange kulturarvsinstitutioners sites mødes brugere traditionelt af meget institutionsnære og teknisk/saglige præsentationer. Fokus er den konkrete institution, dens samlinger og disses brug. Glæden ved historie - både hos institutionernes brugere og personale har sædvanligvis ikke nogen fremtrædende placering. Men H-o vil bl.a. vise, at historie ER sjovt, og at det kan opleves på mange måder - ikke mindst på Nettet. Fx også gennem historiske pc-tapeter og madopskrifter.

To af de lettere resurser, H-o rulleavisen og den danmarkshistoriske almanak med begivenheder for hver dag $\mathrm{i}$ året, er desuden tilrettelagt således, at de kan anvendes af andre sites. Dette er på én gang en enkelt vej til gratis markedsføring af et fælles web-vindue for historien, som $\mathrm{H}-\mathrm{o}$ er, men desuden en resurse til gratis indholdsforøgelse på andre - og måske mindre - sites.

\section{... for børn}

Et juniormodul er efterhånden også kommet op at stå. Det rummer bl.a. to lidt mere omfattende moduler. »Duksen « guider til de bedste skolesider og giver ideer til, hvordan man kan dupere sin dansk- eller historielærer med alternative opgaver, og »Historiepigerne« fra Sæby er et lille an- 


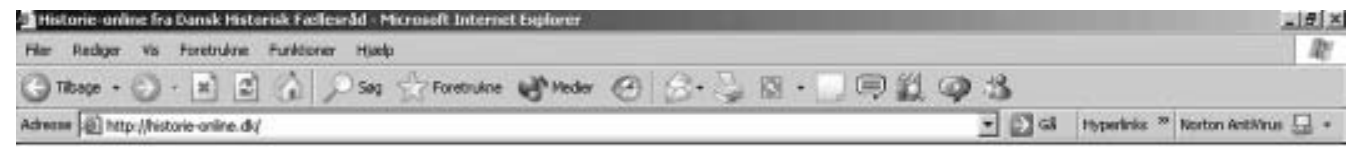
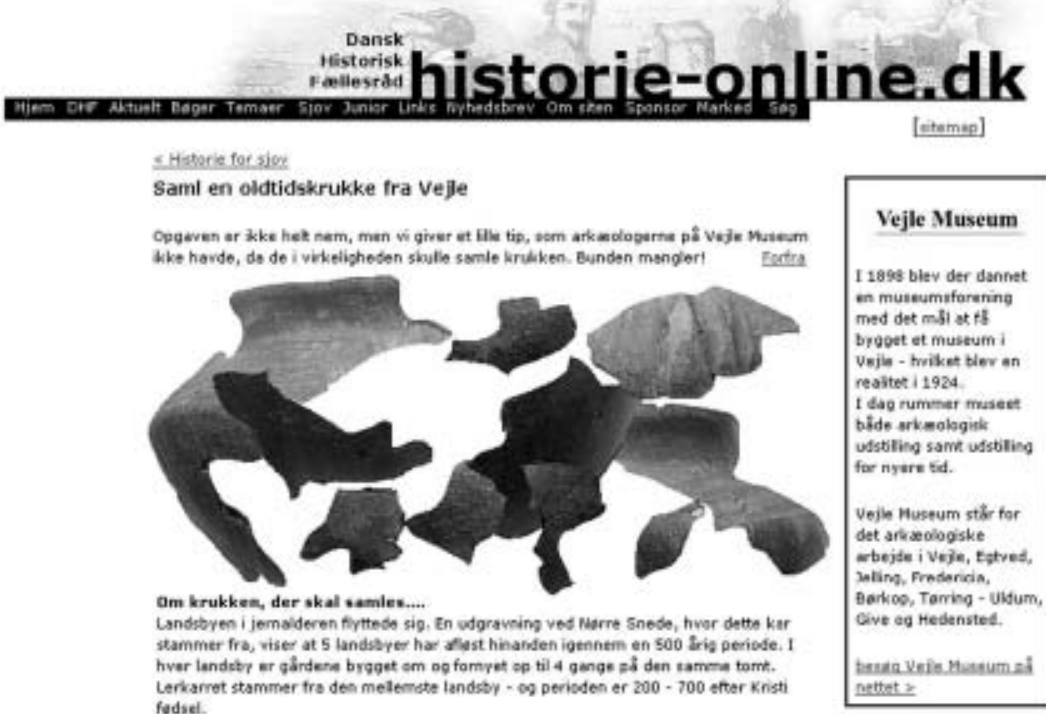

[etemin]

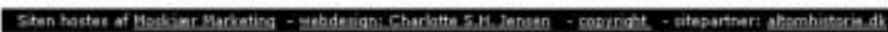

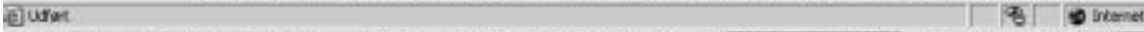

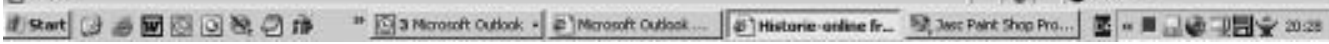

Lidt sjov er der også plads til. Bl.a. kan man teste sine evner som arkaolog ved at samle en jernalderkrukke fra Vejle.

melderkorps af børn, som er ret alternative i deres kommentarer. Her kan man i de seneste anmeldelser bl.a. læse, at tegneserien om Røde Orm er lidt for skrap for pigerne. Det er mere noget for drenge - fordi de efter de unge anmelderes mening »bedre kan hygge sig med halshugninger ..."

»Historiepigerne « er et af de tiltag, som bevidst bidrager til at give siten »ansigter «. Karakteristisk for institutionssites er bl.a., at de i sagens natur fremstår meget overordnet og neutralt. Der er tale om upersonlige størrelser, som har et alment tilbud til »borgerne « som sådan. Det er de færreste, der instinktivt og med forventningsfuld fryd tænker sig ind i rollen som »borger «. Det er ikke umiddelbart tillokkende: hvem vil gerne være upersonlig? At formidle historie er at sælge et budskab, og det er som bekendt de færreste budskaber, der »sælger sig selv«. En effektiv formidling kræver mange overvejelser om målgrupper, delmålgrupper, budskaber og udtryksformer. Enhver deltager i en samtale vil gerne føle, at samtalepartneren er oprigtigt interesseret i kontakt og dialog. For at investere tid og kræfter i dialogen har man som modtager naturligvis også behov for at kunne vurdere, om man nu rent faktisk tilhører den gruppe, som afsenderen vil tale med. De fleste vil gerne mødes venligt og i øjenhøjde. Et sådant møde kræver meget andet end almene kvaliteter som korrekte oplysninger og almindeligt, nogenlunde forståe- 


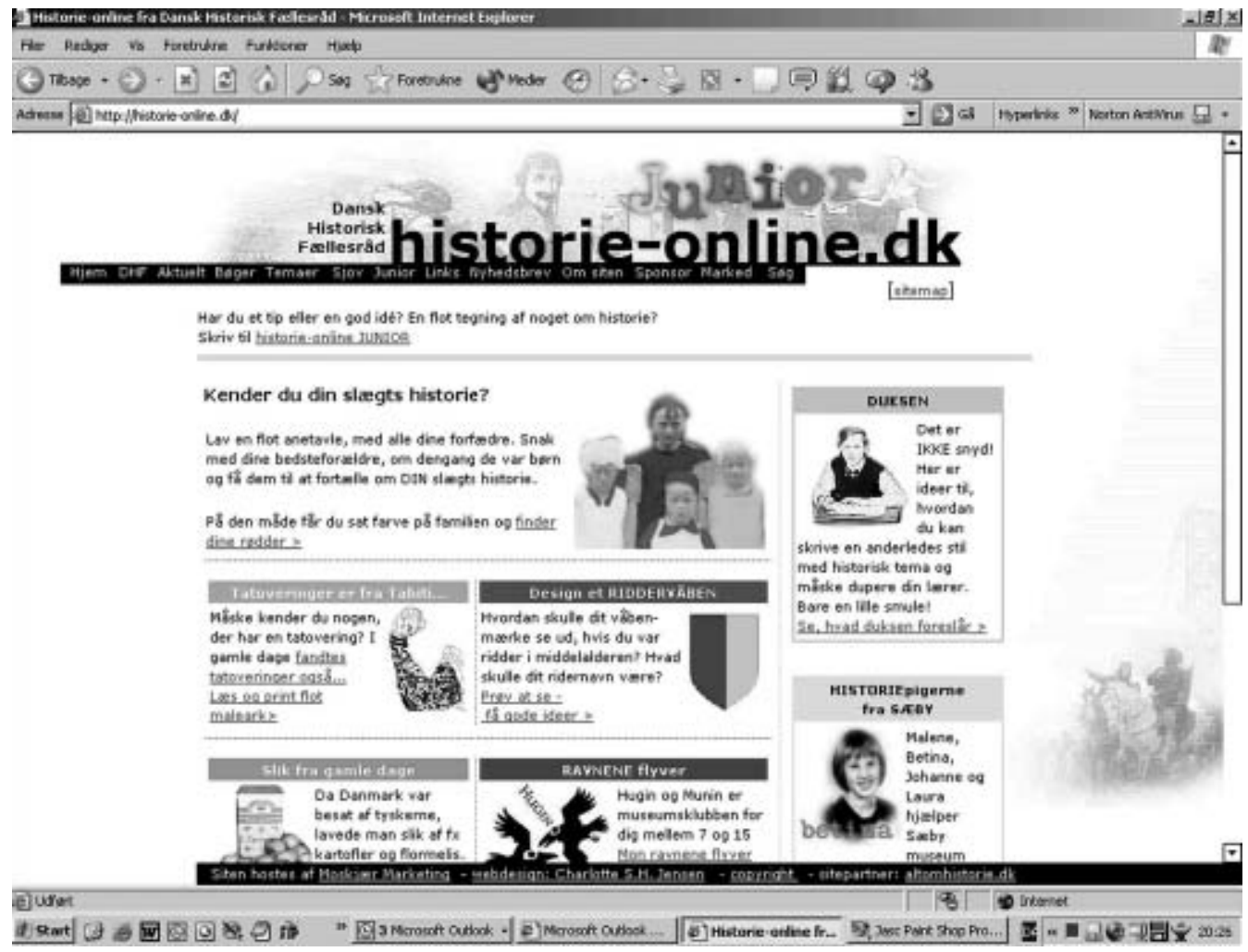

På junior-delen er der forskellige ideer til »historiske « aktiviteter, anmeldelser af børnebøger om historie - og »Duksen« giver ideer til opgaver, der kan dupere dansk- eller historielaereren.

ligt sprog. Begge de nævnte ingredienser er selvsagt vigtige. Men det er mindst ligeså vigtigt, at fx billedmateriale, emnevalg, eksempler - og ægte levende mennesker indgår på en måde, som modtageren kan forholde sig til eller genkende sig selv og egne interesser $\mathrm{i}$.

Det er væsentligt, at man som historieformidler forholder sig til den verden, som alle andre lever i. Fx ved at tage udgangspunkt i aktuelle emner og begivenheder, som vækker bred interesse og genklang i offentligheden. På H-o har vi efter fattig evne og ud fra de begrænsede midler opbygget resurser om fx årets og livets fester, begivenhederne i august 1943, oldtidens perioder, kongelige bryllupper og fødsler m.m. Et lille modul om havehistorie er under udarbejdelse. Der kan naturligvis altid gøres indvendinger imod sådanne valg - fx at det i høj grad er »dame-emner« - men her kommer sitens »personalesituation« naturligvis ind i billedet.

Det er også væsentligt at turde vise »sig selv« som historieinteresseret og historieformidlende person. Formidling er en form for samtale, og de færreste gider tale med en ukendt eller upersonlig samtalepartner. I modsætning hertil signerer H-o's skriverkarle og -piger deres indlæg - fra nyhedsbrev over boganmeldelser til tv-tips. Desuden rummer siten - så ofte det lader sig 
gøre - billeder af relevante personer, både redaktører, skribenter og historieinteresserede. Dette sker for at vise, at den historiske interesse ikke er mere nørdet, end at de fleste kan klare at være med.

Arbejdet med et sådant produkt er selvsagt ikke uden problemer. DHF kæmper faktisk for at holde siten i luften. Et væsentligt problem er, at en stor del af arbejdet udføres frivilligt. Dette er naturligvis ikke holdbart i længden. Andre portaler, fx mik.dk (som dækker arrangementer m.m. på københavnske museer) og den svenske søstersite svenskhistoria.nu har modtaget sponsorstøtte og priser på 250.000 og 500.000 kr. Det bestyrker DHF i håbet om, at det forhåbentlig også skal lykkes for H-o at få en holdbar økonomi og på længere sigt blive uafhængig af frivillig arbejdskraft. En website, der er baseret på jævnlig opdatering og samtidig dybt afhængig af frivillig arbejdskraft, er overordentlig sårbar og uholdbar på længere sigt. Det duer ikke, hvis webmasteren brækker armen, eller to skribenter melder fra. Det har imidlertid vist sig vanskeligt at skaffe stabile, eksterne midler til driften i et sådant omfang, at den kan siges at være sikret. Der arbejdes dog fortsat på at undersøge og udvikle forskellige muligheder og partnerskaber. Som netmedie har H-o ikke umiddelbart en mulighed for at udnytte den dynamik og de formidlingsmuligheder, der ligger i en flermedial strategi. H-o har kun ét medie, eftersom DHF's tidsskrift »Fortid og Nutid « udkommer kvartalsvis og derfor har en helt anden tidshorisont og målgruppe. Blandt de muligheder, som $\mathrm{H}-\mathrm{o}$ arbejder med, er bl.a. site-partnerskaber af forskellig karakter, baseret på forskellige former for interessefællesskaber. Siten har i skrivende stund netop startet et samarbejde med det nye månedsmagasin »Alt om historie«, centreret omkring et spørgeforum og prisen
»Årets historiske bog «. Samarbejdet giver ikke i sig selv øgede driftsmidler, men en værdiforøgelse til begge produkter.

\section{Det lokale: Genvejen til historien - den fynske historie på Nettet}

»Alle vi deltagere skulle - Gud ved af hvilken grund - vare ude på Wembley på en stor plads tre timer, for ceremonien skulle begynde. Den forste time gik med at finde vor plads, spise madpakken osv. Men efterhånden blev vi sure, og det var vel ikke uden grund. Vi torstede, kunne ikke få noget at drikke, da vi kun fandt en vandhane, og den lå et par hundrede meter borte, og den stakkels hane skulle slukke tørsten på 5.000 ... Det stovede, og vore hvide bukser blev efterhånden snavsede. Vi reddede dog en del ved at gå rundt med dem smoget op til knaene. De andre troede, det var vor måde at gå med bukser på, og nogle rystede på hovederne. Dog holdt det imponerende syn og de mange replikker humøret oppe, så at ingen strejkede, da indmarchen langt om laenge begyndte. Vi danske blev som bekendt modtaget med stor jubel af de 80.000 tilskuere, vel nok fordi vi havde legenes smukkeste dragter. Man kan overhovedet ikke beskrive, hvordan det gibber inde i én i de store фjeblikke derovre - det skal opleves selv«.

Ordene er fodboldspilleren Jørgen Leschly Sørensens (1922-1999), født i Lumby ved Odense. Den fynske fodboldspiller var en del af det danske OL-hold i fodbold, der overraskende vandt bronze ved De Olympiske Lege i London 1948. Efter ungdomsfodbold i Lumby kom Jørgen Leschly Sørensen til $\mathrm{OB}$, hvor han debuterede på førsteholdet i 1939. 


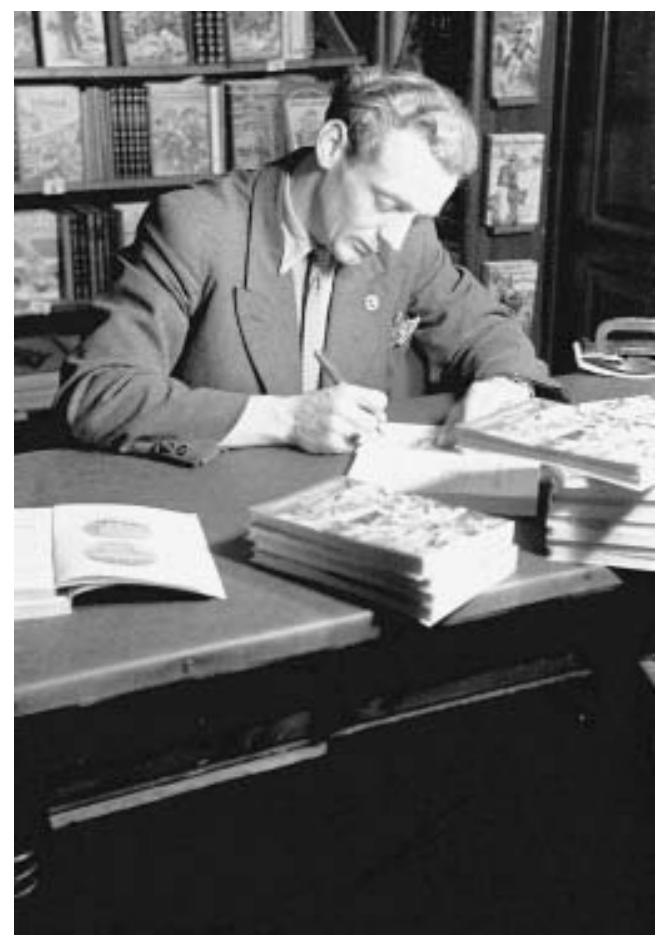

Jorgen Leschly skriver autografer i 1948

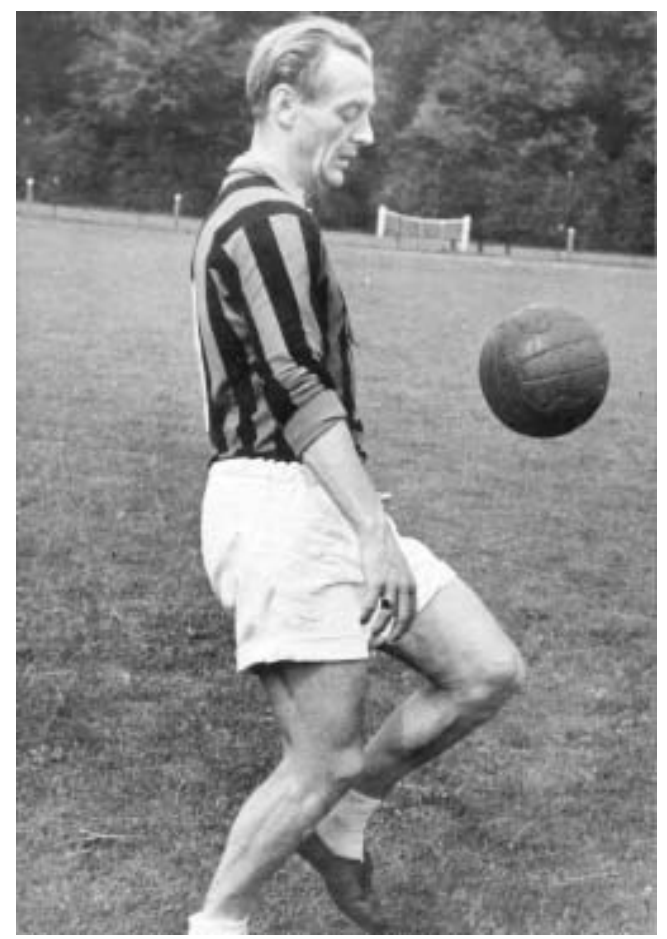

... og »tryller med bolden « omkring 1955 (Odense Stadsarkiv).

han fortæller om sit farverige liv, på arkiv - nemlig Odense Stadsarkiv. Hvis et uddrag af erindringerne ikke var blevet trykt $\mathrm{i}$ Odensebogen i 2004, ville det sikkert kun være en begrænset håndfuld mennesker, der kendte til denne perle af en øjenvidneskildring om en ung mands møde med verdens største idrætsbegivenhed i 1948.

Historien om denne fodboldspillers mere eller mindre glemte erindringer er også historien om alle de spændende historier og kilder, som kan være pokkers svære at finde frem til. På landets arkiver, biblioteker og museer bugner det med opsamlet viden, der blot venter på at blive brugt af historikere, lokalhistorikere og idrætshistorikere, men som desværre ofte ligger ubenyttet hen, fordi folk ikke kender til deres eksistens. Det er ærgerligt, men der er 
hjælp forude. Internettet kan nemlig gøre en forskel!

Det er baggrunden for, at en række (lokal)historiske portaler i de senere år har set dagens lys. En af dem var historiefyn.dk, der var et fors $\varnothing \mathrm{g}$ på at samle lokalhistorisk information fra både arkiver, biblioteker og museer i en fælles portal på Internettet, så brugerne nemmere kunne finde frem til oplysninger.

\section{Hvor findes historien?}

Lokalhistorie har i de senere år oplevet en stigende popularitet. På mange af landets kulturinstitutioner mærker man et stigende $\emptyset$ nske om at finde sine rødder, hvad enten det er slægtens, landsbyens eller byens. Mange har det som en næsten altopslugende hobby at bruge al deres fritid på museer, på arkivernes eller på bibliotekernes læsesale. I begyndelsen skal man have hjælp til at finde kilderne og de gode historier. Hvor skal man overhovedet begynde? Er det på byens lokalarkiv, på biblioteket eller skal man først prøve med et besøg på museet? Heldigvis står mange - både lønnede og frivillige medarbejdere - parate til at yde hjælp disse steder, som udgør en broget mangfoldighed af kulturinstitutioner. Det spænder lige fra det lille foreningsdrevne lokalarkiv eller egnsmuseum til det store regionale og nationale arkiv eller bibliotek.

Trods al mulig velvillig hjælp fra personalet er det tidskrævende, og selv drevne forskere kan bruge enorme mængder af tid på at finde frem til lige netop det materiale, han eller hun har brug for. Det sker ofte, at man må farte fra det ene sted til det andet, før søgningen giver pote. Undervejs risikerer man nemt at løbe forgæves, fordi lige netop de dokumenter, man var overbevist om fandtes på det arkiv, slet ikke ligger der, men et helt andet sted. Ikke alt opbevares der, hvor man umiddelbar skulle tro det!

Det måtte kunne gøres bedre. Sådan omtrent var udgangspunktet, da tre lokalhistoriske arkiver, et bibliotek og to museer på Fyn i samarbejde med Statsbiblioteket i Århus i 2001 igangsatte et pilotprojekt, der skulle vise, at institutionernes historiske samlinger kunne formidles til brugerne på en bedre og mere gennemskuelig måde, hvis man tog Internettets muligheder $\mathrm{i}$ brug. Brugerne skulle i ro og mag kunne sidde foran deres pc og få adgang til både arkivers, bibliotekers og museers samlinger på ét sted. Alt (lokal)historisk materiale under én hat - på en lokalhistorisk portal.

\section{Internettets lyksaligheder}

Resultatet af anstrengelserne blev www. historiefyn.dk, der officielt åbnede den 22 . marts 2002. Siden den dag har fynboerneog alle andre i hele verden - kunnet dykke ned i dele af den fynske historie på Internettet, når de har lyst. Historien er tilgængelig på alle tider af døgnet.

Det var ikke kun på Fyn, at ABM-institutioner (arkiver, biblioteker og museer) i årene efter årtusindskiftet puslede med tanken om en fælles portal til lokalhistorien. Flere institutioner drømte om en hjemmeside, hvor der var mulighed for at søge i arkiver, biblioteker og museers digitaliserede informationer vedrørende lokalhistorie. I Nordjylland så et tilsvarende projekt dagens lys, nemlig NOKS, der var en del af Det digitale Nordjylland (se www.noks. $\mathrm{dk}$ ). Men hvor NOKS fra begyndelsen af satsede på at lægge så mange poster ud som muligt, så var ambitionen i det fynske projekt at indsnævre antallet af poster og til gengæld satse på en bredere formid- 


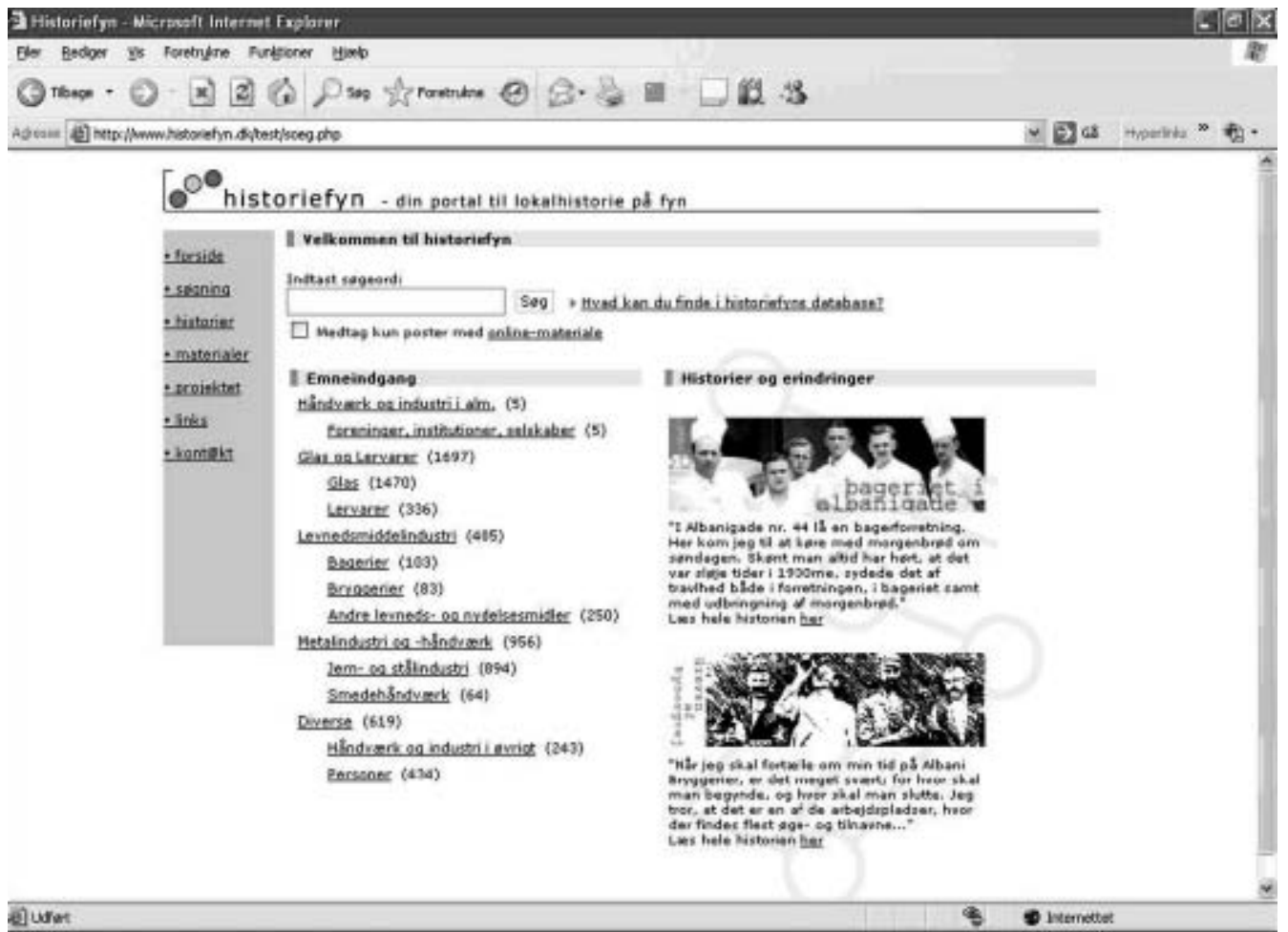

Forsiden fra www.historiefyn. $d k$

lingsdel. Derfor blev pilotprojektet afgrænset til emner, der omhandler sider af håndværkets og industriens historie og udvikling.

Filosofien var simpel. Brugerne skulle ved hjælp af nemme søgemuligheder have adgang til information om, hvad der opbevares på de deltagende arkiver, biblioteker og museer om et givet emne eller en person. Derudover skulle der også være adgang til online erindringsklip, online artikler, digitaliserede billeder og affotograferinger af museumsgenstande.

Alle med interesse for fynsk håndværksog industrihistorie kan med udbytte begynde på historiefyn.dk. Lad os tage et eksempel. Vil man vide noget om Fyens Glasværk, der blev grundlagt i Odense i slutningen af 1800-tallet og først indstillede produktionen i 1990, kan man i historiefyn.dk lave en simpel søgning på »Fyens Glasvark«. Det giver over 50 søgeresultater. En gennemgang af resultaterne viser, at mange af glasværkets produkter - en mangfoldighed af forskellige brugstyper, lige fra simple sutteflasker til smukke vaser i opalhvidt glas - i dag er udstillet på Faaborg Kulturhistoriske Museer. Glassene vises på skærmen, og hvis der er detaljer, man $\varnothing$ nsker at undersøge nærmere, kan man med et enkelt klik se dem forstørret. I søgeresultatet er der også henvisninger til materiale, der ligger på Odense Stadsarkiv, bl.a. en mængde billeder, hvoraf de ældste er fra omkring 1900. Det righoldige materiale giver mulighed for at se, hvordan glasværksarbejderne i praksis bearbejdede det hede materiale, så det fik form og far- 
ve. I den ledsagende tekst til et af billederne får man at vide, at personen, som står $\mathrm{i}$ forgrunden og leder arbejdet, er hyttemester Adolf Brocks. Hans navn dukker i $\varnothing v$ vigt også op i en af museumsregistreringerne fra Faaborg, hvoraf det fremgår, at han er bagmanden bag en meget smuk vase, som man selvfølgelig også ser et billede af. Pludselig fremtræder fortidens aktører mere levende - man laver en kobling mellem den ældre mand på billedet til en kunstgenstand, der 100 år senere står udstillet på et museum.

I søgeresultatet er der også henvisninger til nogle erindringer, der opbevares på Odense Stadsarkiv. Det drejer sig dels om hovedmanden bag glasværket, konsul Frederik Heys erindringer, men også om en arbejders erindringer fra glasværket. Begge erindringer er trykt i Odensebogen 1997, men man behøver ikke at låne bogen, for Olaf Jespersens beretning om arbejdslivet på Fyens Glasværk kan læses i uddrag på historiefyn.dk. Her får man oplyst, hvad en hyttemester egentlig er for en størrelse, og at arbejdet ved ovnene kunne sammenlignes med at befinde sig i Helvedes forgård!

Hvis brugere efter gennemgangen i søgeresultaterne er blevet interesseret $i$ at dykke længere ned i fynsk og odenseansk glasindustri, kan man besøge Odense Stadsarkiv eller Faaborg Kulturhistoriske Museer og få fremlagt originalmaterialet på læsesalen eller se de udstillede glas i museets åbningstid. Man kan også vælge at læse sig frem til mere viden: I søgningen er der en henvisning til Mogens Schlüters bog om Fyens Glasværk. Den bog kan man selvfølgelig bestille elektronisk.

Der findes utallige andre gode oplysninger, billeder, historier, sammenhænge på historiefyn.dk - om f.eks. NKT- kabel og tråd i Middelfart, landsbysmedjerne i Ringe, papirfabrikken i Dalum - for ikke at glemme alle slagterne, bødkerne, tømrerne, snedkerne og bagerne.

De nævnte eksempler på en tværgående søgning i såvel arkivers, bibliotekers som museers samlinger har vist nogle ret åbenlyse fordele. Brugeren får dels nogle relevante oplysninger og sammenhænge præsenteret, men er samtidig kun et enkelt klik fra at kunne kontakte det arkiv, det bibliotek eller det museum, hvor materialet befinder sig. Besøget undgås ikke - heldigvis - men vejen er unægtelig blevet noget nemmere, så brugerne undgår en del unødvendige besøg de forkerte steder. Man er sikker på en succesoplevelse!

\section{Mange erfaringer rigere, men ...}

Historiefyn.dk var kun et pilotprojekt. Derfor var deltagerkredsen også temmelig begrænset, da målet i første omgang var at udvikle muligheden for online samsøgning i ABM-institutionernes gemmer, herunder ikke mindst udviklingen af standardiserede registreringer, som er forudsætningen for fælles databaser.

Målet var, at deltagerkredsen i de kommende år skulle udvides til så mange fynske $\mathrm{ABM}$-institutioner som muligt, så portalen til fulde levede op til sit forpligtende tilnavn - Fyns lokalhistoriske portal - ligesom den skulle dække flere emner og områder af den fynske historie. Alt talte for, at det kunne lade sig gøre. Der var brugt relativt billige teknologiske løsninger. - F.eks. med dataudtrækket fra allerede eksisterende registreringsdata på de enkelte arkiver, biblioteker og museer. Ingen skulle investere i nye og dyre teknologiske løsninger.

Formidlingen var som nævnt vægtet højt i historiefyn.dk. Brugerne skulle have oplevelser og viden serveret sammen med henvisningerne til, hvor originalmaterialet befandt sig. Ideerne til, hvordan denne del 
af historiefyn.dk kunne udvikles, var utallige. I flæng kan nævnes et digitalt Fyns leksikon, digitalisering af lyd og film (en slags historisk biograf Fyn), en digital guide til en historisk tur på Fyn, digitale kort, digitalt undervisningsmateriale. Det var blot nogle af de fremtidsversioner, der er lagt op til.

Erfaringerne fra pilotprojektet var gode, og vi fik mange positive tilbagemeldinger. Historiefyn.dk viste, at førhen umage parland og by, arkiver, biblioteker og museer - sagtens kan samarbejde på lige betingelser, når det gælder det fælles mål at nå ud til et bredt publikum. Basalt handler det vel lige så meget om, at et sådant projekt var med til at styrke, hvad man kunne kalde en fynsk identitet - et forum, hvor kreativitet kan udfolde sig.

Pilotprojektet blev finansieret af Projekt Dansk Identitet, men da pengene slap op, viste det sig desværre mere end vanskeligt at få rejst nye midler, så historiefyn.dk kunne videreudvikles, og mere materiale blive gjort $s ø$ gbart. Der er gjort utallige forgæves fors $\emptyset \mathrm{g}$ på at finde midler til projektets opretholdelse, men penge til den slags hænger ikke på træerne. Der er også blevet ført forhandlinger med Fyns Amt, der har en naturlig »interesse « $\mathrm{i}$ at styrke den fynske identitet, men amtet er under nedlæggelse.

Ideen med samsøgninger i ABM-institutionernes samlinger er god, ikke mindst når det kombineres med formidling. Historiefyn.dk sover i dag tornerosesøvn og vækkes måske aldrig til live igen, men pilotprojektet er fortsat tilgængeligt på Internettet. Derimod lever det nordjyske NOKSprojekt videre - heldigvis. Kulturarvsstyrelsen har også set mulighederne i Internettet og støtter i dag flere museumsprojekter, hvor historien gøres tilgængelig 24 timer i døgnet. Det er blot en skam, at pengene ik- ke også er drysset ud over arkiverne. Det er nemlig ikke mindst på arkiverne, at de gode historier er gemt. Historier som Jørgen Leschly Sørensens erindringer!

\section{Det specielle: NFI - Netvark For Folkelig Idratshistorie}

Da kaptajn Valdemar Mønster i 1861 fik overbevist ledende personer i både nationalliberale og grundtvigianske kredse om, at man skulle stifte Centralkomitéen for oprettelsen af Skytteforeninger havde han næppe forestillet sig, hvilke kræfter han satte i gang. Ud af skytteforeningerne voksede der nemlig en folkelig gymnastik- og idrætsbevægelse, som i dag er samlet under organisationerne Danske Gymnastikog Idratsforeninger (DGI) og De Danske Skytteforeninger (DDS). Den historiske betydning af den folkelige gymnastik- og idrætsbevægelse har været enorm. Ikke blot på det kropslige og idrætslige område har bevægelsen præget Danmark, men også på de politiske, kulturelle, pædagogiske og sundhedsmæssige områder har den folkelige gymnastik- og idrætsbevægelse spillet en stor rolle. Desværre er kendskabet til de historiske kilder fra denne del af vores fælles historie ikke særlig stort, og det er en stor skam, for der ligger megen spændende historie, som blot venter på at blive vakt til live.

Hvem ved fx, at der på Vallekilde $H \phi j-$ skole er bevaret arkivalier - historiske skriftlige kilder - som dokumenterer indførelsen af den svenske gymnastik i Danmark og opførelsen af landets første gymnastikhus? Og at skolens arkiv foruden de gængse forhandlingsprotokoller og regnskaber også rummer en del vandrebøger (brevvekslinger mellem højskoleelever), dagbøger og personarkiver fra nogle af den 


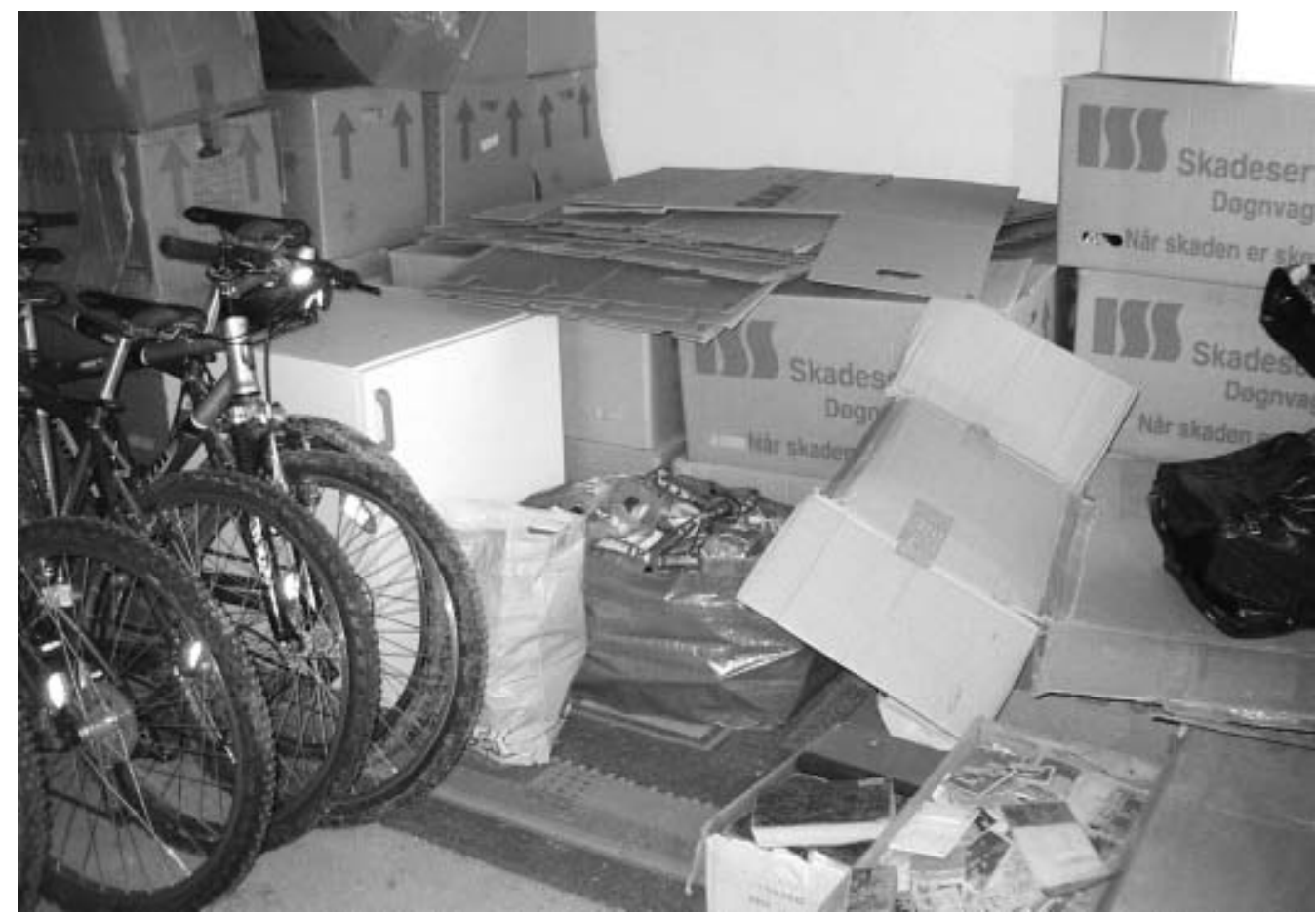

Arkivalier fra Gerlev Idratsh $\phi j$ skole placeret $i$ skolens cykel- og redskabsrum. Stadig pakket i kasser efter branden i 2000 (Vartov-Arkivet).

folkelige gymnastiks pionerer foruden en mængde fotografier? Eller hvem ved, at der på Ryslinge Højskole er arkivalier, som belyser den tidlige delingsføreruddannelse (uddannelse som gymnastikinstruktør) på de danske højskoler? Eller hvem ved, at der rundt om i landet - på amtsforeningernes kontorer - ligger arkivalier, som kan belyse samspillet mellem den folkelige idræt og lokalsamfundets politiske og kulturelle historie?

I foreninger, på højskoler, i lokalarkiver, i private samlinger og andre steder findes rigtig mange af disse kilder, men de er ikke registreret i en form, så de er søgbare - de er så godt som usynlige.

NFI er et fors $\emptyset \mathrm{g}$ på at anvende Internettet til at rette opmærksomheden mod disse skjulte kulturhistoriske skatte. Det er såle- des ikke meningen, at NFI skal være endnu en indgang til allerede eksisterende registre på diverse arkiver og museer. NFI skal i stedet rette opmærksomheden mod kildemateriale fra den folkelige gymnastik og den ikke eliteorienterede idræt, der endnu ikke er indfanget af de eksisterende kulturinstitutioner.

\section{Opbygning af fagligt netværk}

En vigtig forudsætning for, at disse intentioner kan lykkes, er, at der bliver opbygget et tæt netværk til de historikere og andre historisk interesserede, der på forskellig vis arbejder med den folkelige idrætshistorie, således at deres »opdagelser « af interessante historiske kilder kan registreres og formidles videre. I den forbindelse er 


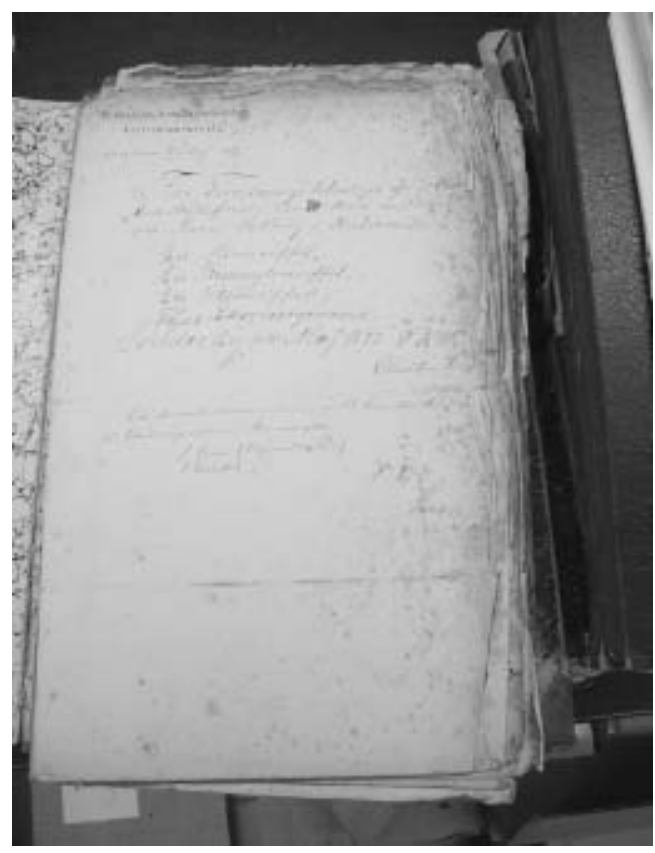

Det var i sidste фjeblik, at arkivet på Borrevejle blev reddet. Arkivet havde $i$ mange år ligget $i$ et fyrrum med storkt skiftende temperaturer (Vartov-Arkivet).

der ved at blive etableret et sådant netværk mellem Vartov-Arkivet - arkiv for folkelige bevagelser, DGI's arkivudvalg, De Danske Skytteforeningers arkiv og Gymnastikog Idratshistorisk Samling.

Vartov-Arkivet kommer i kraft af sit arbejde med de folkelige bevægelsers historie ofte i kontakt med institutioner og enkeltpersoner, som er i besiddelse af interessante historiske kilder, der burde blive kendt af en større kreds. I stedet for at vente $\mathrm{i}$ årevis på, at enten Vartov-Arkivet eller et andet arkiv får registreret og formidlet de fundne arkivalier, kan arkivet give et tip til NFI, som derpå kan fortælle om fundet på hjemmesiden. Et par eksempler:

Gerlev Idratshøjskole var i 2000 udsat for en brand, der udover materiel skade medførte, at skolens arkiv »forsvandt« un- der brandslukningsarbejdet forskellige steder på skolens område. I forbindelse med oprettelsen af Vartov-Arkivet i 2002 blev skolens arkiv eftersøgt, og mange af de »forsvundne « arkivalier blev fundet i kælderrum, cykelskure, skabe og i diverse andre rum. Netop i denne situation kunne NFI være en oplagt mulighed. Ved hjælp af hjemmesiden kunne de mange fotografier, film og arkivalier gøres kendt for en større offentlighed, således at den idrætshistorie, der begyndte i 1938, da Gerlev Idrætshøjskole blev bygget, ikke forbliver gemt og glemt.

Et andet eksempel stammer fra Borrevejle, hvor Vartov-Arkivet via sin kontakt med DGI's arkivudvalg (omtales senere) fik et tip om, at der fandtes et stort arkiv indeholdende arkivalier fra Roskilde Amts Skytteforening, Roskilde Amts Gymnastikforening og selve det folkelige samlingssted Borrevejle. Det var tidligere formand for Roskilde Amts Gymnastikforening, Grethe Jørgensens fortjeneste, at dette arkiv var bevaret og indsamlet. Efter hendes død var man i bestyrelsen for Roskilde Amts Gymnastikforening bange for, at materialet skulle gå til, hvorfor man via DGI henvendte sig til Vartov-Arkivet. Arkivet, som viste sig at være ganske omfangsrigt og dækkede perioden fra 1862 til i dag, ville under normale arkivomstændigheder sagtens have kunnet ligge $\mathrm{i}$ adskillige år, uden at dets righoldige indhold af breve, film, fotografier, regnskaber, medlemsblade og forhandlingsprotokoller blev kendt af idrætshistorikere. Dels fordi de fleste lokal- og specialarkiver ikke har resurser til straks at registrere og formidle materialet, dels - og måske i denne sammenhæng vigtigste årsag - fordi en amtsforening falder i en gråzone mellem det lokale, regionale og nationale. Med NFI åbner der sig mulighed for forholdsvis hur- 


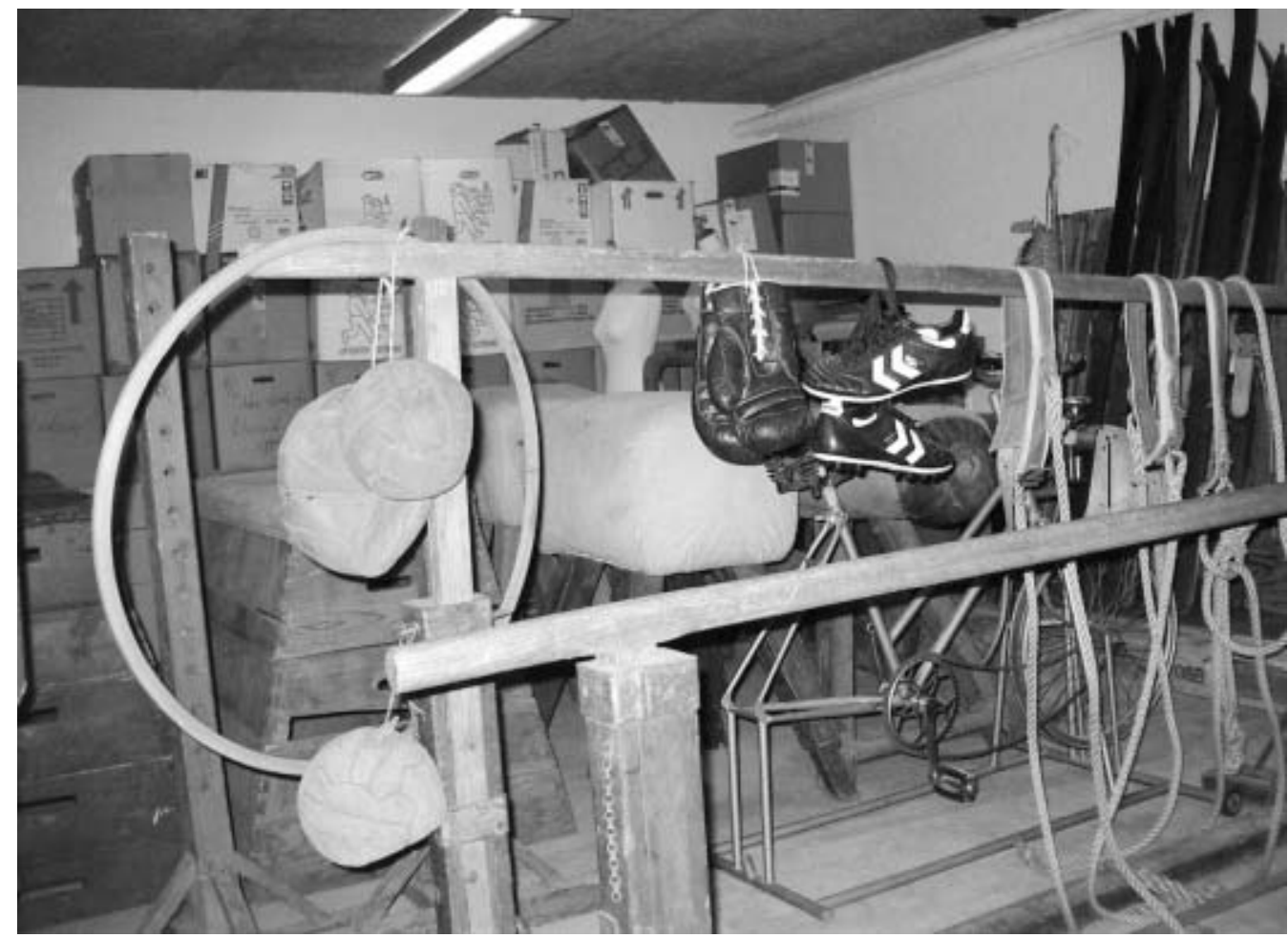

Gymnastik- og Idraetshistorisk Samling (GIS) har som et af de få steder i landet idrcetshistoriske genstande (Vartov-Arkivet).

tigt at løfte dette arkiv ud af gråzonen og frem i lyset.

Et tredje eksempel på, hvorledes VartovArkivet kan anvende NFI, er i forbindelse med studiegrupper, der på forskellige måder beskæftiger sig med idræts- og gymnastikhistorie. Ved at tilknytte studiegrupper af personer, der på den ene eller anden måde har interesse for folkelig idrætshistorie, kan Vartov-Arkivet få viden om idrætshistoriske samlinger og problemstillinger, der hidtil har været ukendt. Meget ofte sidder aktører fra idrætshistorien inde med stor viden om emnet, det kan enten være $\mathrm{i}$ kraft af deres egne erindringer eller i kraft af deres netværk i miljøet. At have et »korps « af meddelere er således af stor værdi for både arkiv og NFI.
DGI's arkivudvalg, der består af tre personer med stor viden om og tæt kontakt til den folkelige idræt, har i nogle år stået bag et storstilet indsamlingsarbejde af arkivalier fra DGI's amtsforeninger. Et mål med dette indsamlingsarbejde har været at samle »gamle« foreningsledere i arkivgrupper, som med deres store lokale berøringsflade kan opstøve de relevante kilder. Nogle af arkivgrupperne har arbejdet meget seriøst med opgaven og har haft ugentlige arbejdsmøder, hvor man har ordnet de arkivalier, man har indsamlet. På amtskontoret i Ulfborg er det fx blevet til eget idrætshistorisk arkiv med åbningstider. En anden positiv effekt ved arbejdet i amtsforeningerne er, at disse fungerer som en slags åbne historiske værksteder, hvor yngre for- 
eningsfolk ofte lige skal se, hvad »de gamle« sysler med. På den måde fungerer dette arkivarbejde som praktiseret folkeoplysning, hvor historien bliver levende i nutidens foreningsarbejde. Disse »gamle « foreningsledere kunne samtidig være vigtige informanter til NFI.

De Danske Skytteforeninger har i hovedkontoret i Vingsted oprettet et historisk arkiv primært med skyttebevægelsens arkivalier. Samlingen er meget omfattende og vigtig, hvis man ønsker at forske i eksempelvis den organisatoriske side af den folkelige idrætshistorie. Tillige har arkivet en meget stor filmsamling, der kunne fortjene en større udbredelse. NFI kan her spille en vigtig rolle i udbredelsen af kendskabet til dette centrale kildemateriale fra den folkelige idrætshistorie.

Gymnastik- og Idratshistorisk Samling i Viborg rummer arkivet fra Dansk Landsdelingsførerforening, arkivet for Gymnastikhøjskolen ved Viborg, personarkivet fra den tidligere forstander for højskolen, Mads Nielsen, en komplet samling af tidsskriftet Ungdom og Idræt og utallige gamle gymnastik- og idrætsfilm fra de folkelige idrætsorganisationer. Film, som nu for en stor del er overspillet til dvd og kan udlånes. Tilmed har Gymnastik- og Idrætshistorisk Samling foruden arkivalier også indsamlet idrætshistoriske genstande, noget, der ellers er meget sjældent i den danske museumsverden. Det er muligt at se og føle på en gammel plint, skiudstyr, boksehandsker osv.

Gymnastik- og Idrætshistorisk Samling i Viborg har samme problem som De Danske Skytteforeningers arkiv. På trods af en spændende samling har det ikke været muligt at søge på indholdet af materialet, bl.a. fordi der ikke eksisterer en tilgængelig registratur. Også her ville NFI med fordel kunne anvendes.

\section{NFI dækker gråzonerne}

For disse forskellige institutioner kan NFI være et vigtigt redskab til hurtigt og forholdsvis nemt at formidle de mange spændende arkivalier. NFI kan afkorte den tid, der går fra »opdagelsen « af interessante arkivalier, til disse bliver formidlet. Den store udfordring er - hvordan? Gør man som i arkivverdenen - hvor erfaringen viser, at registrering af arkivalier, fotografier og film ofte er en langsom og omstændelig affære - er man jo lige vidt. Projektets $\varnothing$ konomiske rammer giver i $\varnothing$ vrigt ingen mulighed for en tilbundsgående registrering. Derfor har det været nødvendigt at konstruere en database, som skal være let at anvende - både for dem, som skal indtaste oplysninger i den, og for dem. som søger i den. Denne del af projektet er mere dybtgående beskrevet $\mathrm{i}$ artiklen $\gg$ Digital folkelighed? «

Men vigtigst er det, at NFI dækker en gråzone indenfor indsamlingen af den folkelige idrætshistorie. Nemlig arkivalierne fra de højskoler, amtsforeninger og aktører, der ikke er lokalt forankret, men enten regionale eller nationale. Disse arkivsamlinger falder ofte igennem lokalarkivernes ellers fintmaskede net, og de har slet ikke det statslige arkivvæsens opmærksomhed. Ganske vist fors $\varnothing$ gte det statslige arkivvæsen for nogle år siden via en spørgeskemaundersøgelse at registrere, hvorledes det stod til med arkiverne på de danske højskoler og landbrugsskoler, men henvendelsen blev ikke vel modtaget på de respektive skoler. Sikkert, fordi statens myndigheder hos de frie skoler traditionelt ikke møder stor tillid. Endnu et fors $\emptyset \mathrm{g}$ på at registrere disse arkivalier blev gjort i 2005, bl.a. i samarbejde med Vartov-Arkivet, men ansøgningen om $\varnothing$ konomisk støtte blev afvist af kulturministeren. 


\section{Til inspiration}

NFI-hjemmesiden skulle også gerne inspirere alle historisk interesserede til at anvende andre kildetyper end de gængse, såsom forhandlingsprotokoller og regnskaber. Netop ved også at kaste lys på kildetyper som vandrebøger, brevsamlinger, materiale fra festtraditioner (sange, revytekster og programmer), foredragsvirksomhed, gymnastikprogrammer, øvelsesoversigter, fotografier, dagbøger osv. er det håbet, at dagliglivet, de kulturelle mønstre og de sociale aspekter ved den folkelige gymnastik- og idrætshistorie i større grad kan få en plads i historieforskningen.

Forhåbentlig vil et $\emptyset$ get fokus på netop disse områder af den folkelige historie virke tilbage på arkivskaberne og arkivejerne, så der ikke uforsætligt kasseres værdifuldt kildemateriale, som kan fortælle om de kulturelle og sociale dimensioner af den folkelige idræt. Det er nemlig vigtigt at forstå, at historisk forskning og skrivning hænger uløseligt sammen med indsamling. Hvad historieskrivningen sætter lys på og anvender af kilder definerer samtidig, hvad ikke-historikere opfatter som rigtige kilder.

\section{Hvordan er det gået?}

Som det fremgår af foranstående har der været mange intentioner og ideer, men hvordan er det så gået?

I den forholdsvis korte periode hjemmesiden har været under opbygning, har det vist sig særdeles vanskeligt få etableret en stabil kontakt til ejerne af de kildesamlinger, der ligger rundt omkring i landet på højskoler, hos enkeltpersoner og i foreninger. Forventningen om, at den brugervenlige cd-rom med database ville blive anvendt af arkivejerne og dermed danne rygraden i hjemmesiden, er ikke blevet ind- friet. En forklaring herpå er formentlig, at projektet ikke har haft kapacitet til at følge henvendelserne op med personlige kontakter - et besøg på stedet er stadigvæk den bedste måde at skabe en kontakt på.

Desuden har det vist sig nødvendigt, at alle data tjekkes, før de lægges ind på hjemmesiden. Dette skal gøres, så oplysninger, som på den ene eller anden måde kan skade enkeltpersoner, ikke slipper ud til offentligheden. På den måde er databasen underlagt de samme arkivregler om tilgængelighed, privatlivets fred og copyright som de lokalhistoriske arkiver.

Endelig har det vist sig at være en mere langsommelig proces end forventet at få etableret et samarbejde med de enkeltpersoner og institutioner, der har arkivalierne. Ikke fordi viljen mangler, men snarere fordi det er vanskeligt for eksempelvis højskoler at afsætte tid og personale til at foretage de nødvendige registreringer i databasen.

På trods af disse problemer har projektet vist, at der rundt omkring i landet, i foreninger, på højskoler og hos enkeltpersoner, findes en stor mængde vigtigt og spændende kildemateriale fra den folkelige gymnastik og idræt, som kunne fortjene at blive kendt af historisk interesserede og studerende. Projektet har også demonstreret, at den $ø$ gede opmærksomhed på de kulturelle og sociale aspekter af den folkelige historie har haft en positiv virkning på, hvad der bevares.

\section{Falles afslutning}

Hvad de tre eksempler på formidling af historie på Internettet viser er, at der foruden de indlysende fordele også er en række problemer ved denne formidlingsform.

At projekterne i så stor udstrækning hviler på frivilligt arbejde, er både en styrke og svaghed. Det er en styrke, fordi det ska- 
ber et stort og vigtigt netværk blandt de almindelige brugere, men det gør også projekterne $\varnothing$ konomisk skrøbelige. Nyudvikling og vedligeholdelse af hjemmesider koster penge og kræver uddannede ansatte, hvis kvaliteten skal holdes og helst højnes. Jagten på sponsorer er vigtig, men også trættende og resursekrævende. Risikoen er, at det, som er sat i gang, lige så stille $\mathrm{d} \emptyset \mathrm{r}$ ud.

Et andet problem er, at hjemmesiderne har en tendens til at fremstå upersonlige, $o g$ at man derfor ikke fornemmer, at der bag den kolde teknik befinder sig engagerede og virkelige mennesker, der brænder for at fortælle om deres historiske viden.

Et tredje problem er, hvordan de sparsomme $\varnothing$ konomiske midler anvendes. Hvis pengene hovedsagelig anvendes til at lave tjekkede og indbydende hjemmesider på bekostning af det indholdsmæssige, vil projekterne med tiden dø ud. Det er vigtigt, at der også afsættes midler til det lange »seje træk « med det mindre glamourøse arkivarbejde. Uden en ordentlig arkivmæssig substans vil hjemmesiderne med tiden tørre ud.

Og endelig er det et problem, hvordan samarbejdet mellem de mange forskelligartede institutioner sikres. Skal der oprettes en form for styregruppe? Eller skal der afholdes jævnlige arbejdsmøder, hvor erfaringer og viden kan udveksles? Det er nogle af de problemer, som det i den nærmeste fremtid er nødvendigt at finde en løsning på.

Spørgsmålet er, om danskernes store støtte til bevarelse af kulturarven også gælder, når det koster penge, for uden økonomisk støtte bliver der ingen professionel bevarelse og formidling af kulturarven. 